\title{
Risk of exposure of farms and subsistence nurseries to contact with wild boar in southern Mato Grosso do Sul ${ }^{1}$
}

\author{
Paulo H. Braz ${ }^{2 *}$ (D), Maxwell R. Oliveira ${ }^{3}$, Virgínia S. Silva ${ }^{4}$, Walfrido M. Tomas ${ }^{5}$, \\ Raquel S. Juliano ${ }^{5}$, Thamy A. Moreira ${ }^{3}$, Namor P. Zimmermann ${ }^{6}$ and \\ Aiesca O. Pellegrin ${ }^{5}$
}

\begin{abstract}
Braz P.H., Oliveira M.R., Silva V.S., Tomas W.M., Juliano R.S., Moreira T.A., Zimmermann N.P. \& Pellegrin A.O. 2019. Risk of exposure of farms and subsistence nurseries to contact with wild boar in southern Mato Grosso do Sul. Pesquisa Veterinária Brasileira 39(2):148-154. Universidade Federal de Mato Grosso do Sul, Cx. Postal 549, Campo Grande, MS 79070-900, Brazil. E-mail: pauloh.braz@hotmail.com

With the advancement of wild boar distribution in the rural environment, its impacts are not limited to health in the pig sector, but the requirements for monitoring and control of the species are requirements laid down by the OIE for the recognition of classical swine fever free zone status. The construction of ecological models of favorability or suitability for the occurrence of pest species are necessary tools for the decision making on priority areas of management aiming at risk management. This work aims to map the level of suitability for the occurrence of wild boar in the southern state of Mato Grosso do Sul, as well as to identify the main risk variables for contact with the wild boar and evaluate the biosecurity measures adopted by commercial farms integrated in the south of the State of Mato Grosso do Sul. To evaluate the risk potential of wild boar for commercial and subsistence swine farming in southern Mato Grosso do Sul, a model of environmental suitability was constructed for this species in the swine producing region. This model considered different environmental strata, being the selection of the layers considered the physiological and behavioral characteristics of the species. In parallel, interviews were carried out in a sample of commercial farms integrating the region to survey the perception of the presence of the invasive species and the biosafety measures adopted. The results of this work indicate that the risk of contact among wild boars and animals reared in closed production systems may be high in the study area and only establishment of appropriate biosecurity measures that consider the characteristics and habits of the boar may prevent the intrusion of this species and contact with domestic swine. The built model can be considered of high reliability and it is recommended to apply it to other areas of the state, being a useful tool for the productive sector, environmental agencies and decision makers.
\end{abstract}

INDEX TERMS: Exposure farms, nurseries, wild boar, Mato Grosso do Sul, landscape epidemiology, biosegurity, pig production system.

\footnotetext{
${ }^{1}$ Received on August 11, 2018.

Accepted for publication on August 24, 2018.

${ }^{2}$ Docente do Instituto Federal Farroupilha, Linha 7 de Setembro BR-386 Km 40, Centro, Frederico Westphalen, RS 98400-000, Brazil. *Corresponding author: paulo.braz@iffarroupilha.edu.br

${ }^{3}$ Universidade Federal de Mato Grosso do Sul (UFMS), Avenida Costa e Silva s/n, Pioneiros, Campo Grande, MS 79070-900, Brazil.

${ }^{4}$ Empresa Brasileira de Pesquisa Agropecuária (Embrapa Suínos e Aves), Concórdia, SC 89700-000, Brazil.

${ }^{5}$ Empresa Brasileira de Pesquisa Agropecuária (Embrapa Pantanal), Rua 21 de Setembro 1.880, Nossa Senhora de Fátima, Cx. Postal 109, Corumbá, MS 79320-900, Brazil.

${ }^{6}$ Centro Universitário da Grande Dourados (Unigran), Rua Balbina de Matos 2121, Jardim Universitário, Dourados, MS 79824-900, Brazil.
}

RESUMO.- [Risco de exposição de granjas e criatórios de subsistência ao contato com javalis no sul do Mato Grosso do Sul.] Com o avanço da distribuição do javali no ambiente rural, seus impactos não se restringem somente a sanidade suidea, embora as exigências quanto ao monitoramento e controle da espécie sejam exigências previstas pela OIE, para o reconhecimento do status de zona livre de peste suína clássica. A construção de modelos ecológicos de favorabilidade ou adequabilidade para a ocorrência de espécies-praga são ferramentas necessárias para as tomadas de decisão sobre áreas prioritárias de manejo visando gestão de risco. Este trabalho objetiva mapear o nível de adequabilidade para 
a ocorrência de javalis no sul do Estado de Mato Grosso do Sul, bem como levantar as principais variáveis de risco para o contato com o javali asselvajado e avaliar as medidas de biosseguridade adotadas por granjas comerciais integradas no sul do Estado do Mato Grosso do Sul. Para avaliar o potencial de risco exercido pelos javalis para a suinocultura comercial e de subsistência nesta região foi construído um modelo de adequabilidade ambiental para essa espécie na região produtora de suínos. Esse modelo considerou diferentes estratos ambientais, sendo que para a seleção das camadas consideram-se características fisiológicas e comportamentais da espécie. Em paralelo, entrevistas foram realizadas em uma amostragem de granjas comerciais de integração da região para levantamento da percepção quanto a presença da espécie invasora e as medidas de biossegurança adotadas. Os resultados desse trabalho indicam que o risco de contato entre javalis de vida livre e os animais criados em sistemas de produção fechados pode ser alto na área de estudo e somente estabelecimento de medidas de biosseguridade apropriadas, que considerem as características e hábitos do javali poderá impedir a intrusão dessa espécie e o contato com os suínos domésticos. 0 modelo construído pode ser considerado de elevada confiabilidade e recomenda-se a sua aplicação para as outras áreas do estado, sendo uma ferramenta útil para o setor produtivo, os órgãos ambientais e os tomadores de decisão.

TERMOS DE INDEXAÇÃO: Exposição de granjas, criatórios, javalis, Mato Grosso do Sul, epidemiologia espacial, biosseguridade, suíno cultura.

\section{INTRODUCTION}

Brazil occupies the fourth place in the global ranking of production and exportation of swine meat and represents $7.8 \%$ of the amount of swine meat exported around the world in the year of 2015, with an exportation of 555 thousand tons (ABPA 2017). Meanwhile, the state of Mato Grosso do Sul (MS), Brazil, slaughtered 1.4 million swine in 2015, reaching 127.1 thousand tons of meat, an increase of $7.1 \%$ over the previous year, according to data of the Federation of Agriculture and Livestock of Mato Grosso do Sul (Federação da Agricultura e Pecuária de Mato Grosso do Sul - Semagro 2016).

The main threats to the guarantee of access to the international market are the sanitary issues of production, which is why the production chain of swine farming has been guided by its actions to comply with the standards established by the World Organization for Animal Health (OIE). One of the main goals of this sector is the establishment and maintenance of the status of free zone of Classical Swine Fever (CSF), according to the sanitary code of the terrestrial animals, followed by the National Suidae Health Program (Programa Nacional de Sanidade Suídea - PNSS) (Salgado et al. 2015, Zanella et al. 2016). The PNSS provides biosecurity norms and control of some endemic diseases for Certified Suidae Breeder Farms (Granjas de Reprodutores de Suídeos Certificados - GRSC), while in other types of farms only some diseases listed by the OIE are predicted to control.

Biosecurity is defined as the implementation of measures that reduce the risk of introduction and spread of etiological agents in a herd or flock. The main elements of biosecurity are segregation, where barriers to limiting opportunities of entry of infected animals or contaminated materials into a healthy herd are created and maintained (FAO/OIE/WB 2010).

Normative Instruction (IN) No. 25 (Brasil 2016) of July 19th, 2016 declares that the animals of the species Sus scrofa, that includes boar and wild boars in free life, are considered swine, being necessary for the State that wishes to export to be considered free of classical swine fever.

Wild boar, original from Eurasia, is an exotic species in the Brazilian territory and, in recent years, has shown an uncontrolled population increase (Salvador \& Fernandez 2014). Exotic species considered invasive that have the capacity to move long distances are considered to be a major threat to local biodiversity and generate great impacts on agricultural activities (Wittenberg \& Cock 2001). Wild boars affect the dynamic of the soil and of water bodies, they feed on birds and from eggs of species that nest in the soil, prey on seeds, and alter the regenerative ability of forests (Lowe et al. 2000).

There are data that demonstrate the distribution of this species worldwide (Mitchel-Jones et al. 1999, Afonin et al. 2008, IUCN 2012), although the given geographic informations are limited, mainly coming from data ceded by hunters (Servanty et al. 2011). The wild boars use reforested areas as refuge, especially in places where the weather is warm or very cold. High temperatures favor the propagation of the species, which facilitates the search for different sources of protein and carbohydrates to maintain their energy (Bieber \& Ruf 2005, Melis et al. 2006).

The construction of ecological models of favorability or suitability for the occurrence of pest species are necessary tools for decision making on priority areas for management aiming at risk management.

This study aimed to map the level of suitability for the occurrence of wild boars in the South of the Mato Grosso do Sul state, to identify the main risk variables for the contact with the wild boar, and to evaluate the biosecurity measures adopted by commercial farms integrated in this region.

\section{MATERIALS AND METHODS}

Study area.14 commercial swine farms were visited, located in an area of $37767.025 \mathrm{Km}^{2}$ (Fig.1) in the South of Mato Grosso do Sul state, in the municipalities of Rio Brilhante, Itaporã, Dourados, Vicentina, Jateí, Glória de Dourados, and Ivinhema, all belonging to an integrated production system. This sample corresponds to $100 \%$ of the commercial farms of the region. The Southern region of the state was chosen because it is an area known for the presence of wild boars and is the region with the highest concentration of swine farms in the state. Among the farms, 9 were piglet production units (PPU), 2 termination unit farms (TU), 2 nurseries (FN) and a complete cycle farm (CC). At the same time, 32 settlements for swine production for subsistence were selected by sortition in the Southern region of Mato Grosso do Sul, 16 settlements in the municipality of Deodápolis, 4 in Angélica, 9 in Rio Brilhante, and 3 in Nova Alvorada do Sul.

Interviews. The collection of information occurred through semi-structured interviews, from January 2017 to July 2017. The issues aimed at raising the biosecurity measures adopted in the production units and the perception of those responsible in relation to the risk represented by the wild boar such as: the presence of wild boar in the vicinity of the farm; occurrence of wild boar invasion on the farm and contact with these animals; proximity to forested areas and agriculture area; possible contact amongdomestic swine 

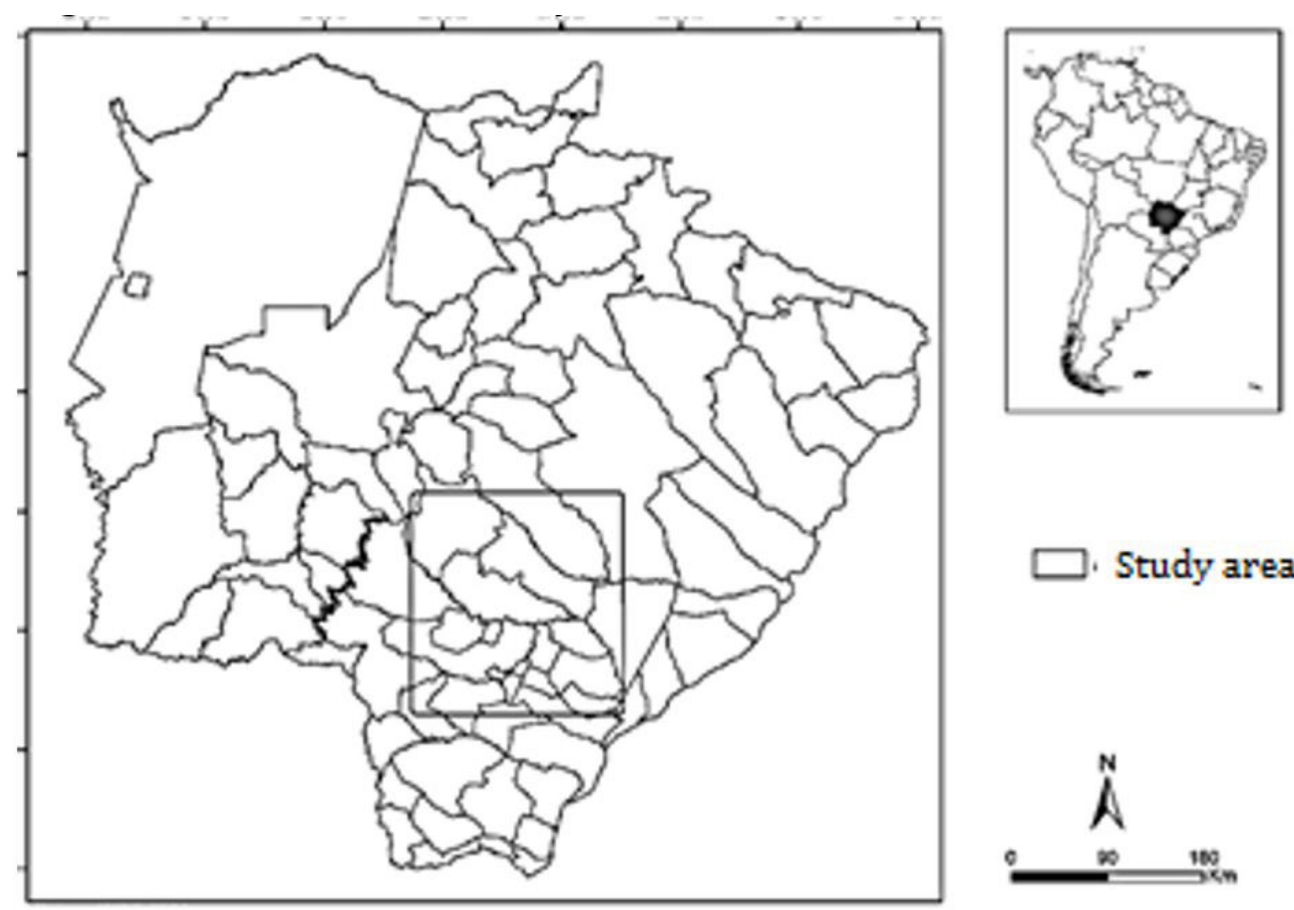

Study area

Fig.1. Location of the study area in the south of Mato Grosso do Sul.

with wild boars, practices for contact prevention; and knowledge related to biosecurity. In the interview the denomination wild boar was used to indicate pure animals and all their hybrids, wild boars in free life and the so-called javaporco, domesticated swine crossed with wild boar or domesticated swine crossed with javaporcos, as described by PNSS.

Survey of farms' biosafety measures. The farms' biosafety measures were recorded by photographic images, in accordance with the standards for certification of suidae breeding farms, in the Annex to Normative Instruction SDA No. 19 of February 15, 2002. The biosecurity measures of the swine farms visited were documented by photographic images, especially those related to the prevention of entry of the wild boar in the facilities: quality of isolation of the farm - fences and quality of isolation of the farm green belt by photographic images; images of the fences of swine to evaluate the biosecurity measures and the practices used to prevent contact amongwild boars and their hybrids with domestic swine .

Environmental suitability model for the wild boar. The soil cover classes used were selected considering the physiological and behavioral characteristics of the species. Six classes were selected: forest environments, wetlands, water bodies, corn crop, sugarcane plantations and settlements (Table 1), where subsistence farms were also considered (Braz 2017). In order to evaluate the potential risk of wild boars on commercial swine farms, different environmental strata were selected (Table 1) and the ranking was established according to Bosch et al. (2016), using expert opinion assessments on the suitability of wild boar habitat for different classes of soil cover (Table 2). Forest areas are considered to be at greater risk, followed by tree areas mixed with lawn areas, wetlands, plantation areas, and finally, urban areas.

The maize and sugarcane crops, as well as settlements, were acquired from the SISLA system (sisla.imasul.ms.gov.br), from the Mato Grosso do Sul government. The other classes were generated from the Supervised Classification technique, in the Spring 5.5 program.
Table 1. Level of relevance of soil cover classes for wild boars (Sus scrofa) used in the construction of environmental suitability models for the species in Southern Mato Grosso do Sul, Brazil

\begin{tabular}{lc}
\hline \multicolumn{1}{c}{ Coverage classes } & Relevance level (\%) \\
\hline Forest environments & 20 \\
Wet areas & 20 \\
Water bodies & 20 \\
Corn crop & 15 \\
Cane plantation & 15 \\
Settlement & 10
\end{tabular}

Table 2. Weight attributed to distance ranges from soil cover classes used to model suitability for wild boar

(Sus scrofa) in Southern Mato Grosso do Sul, Brazil

\begin{tabular}{lc}
\hline \multicolumn{1}{c}{ Distance zones } & Weight \\
\hline $0 \mathrm{~km}$ & 100 \\
From 0.01 to $1.00 \mathrm{~km}$ & 80 \\
From 1.01 to $2.00 \mathrm{~km}$ & 60 \\
From 2.01 to $3.00 \mathrm{~km}$ & 40 \\
From 3.01 to $4.00 \mathrm{~km}$ & 20 \\
Above $5 \mathrm{~km}$ & 5
\end{tabular}

In the classification were used images of the satellite Sentinel 2, with spatial resolution of 10 meters, dated from July 2017, obtained from the website of the United States Geological Survey (USGS).

The environmental layers used in the modeling corresponded to the distance zones of each of the soil cover classes, using the tool "Euclidean Distance" of the program Arcgis, version 10.1. The distance zones were from $0 \mathrm{~km}, 0.01$ to $1.00 \mathrm{~km}$, from 1.01 to $2.00 \mathrm{~km}$, from 2.01 to $3.00 \mathrm{~km}$, from 3.01 - $\mathrm{km}$ to $4.00 \mathrm{~km} 4.01$ to $5.00 \mathrm{~km}$ and $\geq 5.00 \mathrm{~km}$ of distance from each one of the classes of soil cover, corresponding 
to the environmental layers used in the modeling. The limit of $5 \mathrm{~km}$ corresponds to the maximum distance that these animals can travel throughout their life (Salvador \& Fernandez 2014). Classes that were available throughout the year had a greater weight (forests, water and wetlands) followed by temporary resources (corn and sugarcane plantations) as well as settlements - included by the risk of attracting wild boars due to the lack of biosecurity (Braz 2017) and the presence of females of reproductive age, characteristics of subsistence creation. Weights corresponding to the relevance of each soil cover class (Table 1) as well as the different distance ranges of these classes (Table 2) made up the environmental layers used in the modeling of environmental suitability for the wild boar. For the elaboration of the environmental suitability map, the Arcgis weighted overlay tool was used. This tool requires the assignment of a level of influence of each class and weights for each of these distance ranges (Table 1 and 2).

Risk of contact. The analysis of the risk of contact among farms and subsistence farms with wild boars was based on the environmental suitability model for this species. Each property was plotted on the map of environmental suitability and buffers were

Table 3. Average and standard deviation $( \pm$ SD) of the percentage of coverage of the different levels of environmental suitability for the wild boar (Sus scrofa) in areas of 1, 2, and 5 kilometers radius around commercial farms and subsistence farms in Southern Mato Grosso do Sul, Brazil

\begin{tabular}{lcc}
\hline \multicolumn{3}{c}{ Subsistence breeding } \\
\hline Levels of suitability & \% Average \pm SD & \% Average \pm SD \\
\hline $1 \mathrm{~km}$ & 0 & 0 \\
Low & $28.3 \pm 4.6$ & $44.5 \pm 25.3$ \\
Medium & $82.1 \pm 3.7$ & $78.6 \pm 10.1$ \\
High & $44.4 \pm 17.3$ & $16.7 \pm 12.6$ \\
Very high & & \\
2 km & 0 & 0 \\
Low & $20.9 \pm 3.51$ & $28.9 \pm 14.4$ \\
Medium & $81.9 \pm 3.25$ & $77.2 \pm 7.7$ \\
High & $46.7 \pm 8.8$ & $17.4 \pm 7.9$ \\
Very high & & \\
5 km & 0 & 0 \\
Low & $26.2 \pm 4.2$ & $76.0 \pm 6.4$ \\
Medium & $70.4 \pm 3.8$ & $19.7 \pm 6.4$ \\
High & $18.6 \pm 18.7$ &
\end{tabular}

defined around them, centralized in the exact location of breeding sites/farms. These zones were defined as 1, 2 and $5 \mathrm{~km}$ radius, within which the coverage percentage of each adequacy level (low, medium, high, very high) was calculated and considered as a risk indicator (Table 3).

\section{RESULTS AND DISCUSSION}

In Brazil, establishment biosafety standards are only for Certified Suidae Breeder Farms (Granjas de Reprodutores de Suídeos Certificados - GRSC). This is highly relevant since in situations of high environmental suitability for wild boars, farms with low biosecurity become susceptible to contact among the wild species and domestic swine. For Bellini et al. (2016) it is of fundamental importance the physical isolation of the production establishments, preventing an infected freeliving animal from having contact with the animals of the herd. As the state of Mato Grosso do Sul is currently in areas free of classical swine fever, according to the OIE, the maintenance of this status is a concern that must be considered by both producers and public authorities.

For sanitary risk management, it is essential to know the areas with the greatest potential for occurrence of wild boar, which can be accessed through maps of environmental suitability for this species, especially when it is known that this species already has a wide distribution in the region. The proximity of the property to the different levels of environmental suitability for the wild boar can be an indicator of contact risk. The results of this study show that, on average, most of the areas up to $1 \mathrm{~km}$ in the vicinity of subsistence nurseries analyzed are constituted by areas of high $(82.1 \% \pm 3.7)$ and very high (44.4\% \pm 17.3 ) environmental suitability for wild boar; areas up to $1 \mathrm{~km}$ in the vicinity of commercial farms are composed of zones of high $(78.6 \% \pm 10.1)$ and very high $(16.7 \% \pm 12.6)$ environmental suitability for the species (Table 3 ). This condition does not change substantially at greater distances, such as 2 and $5 \mathrm{~km}$ from commercial farms and subsistence farms (Table 3). The results suggest an exposure to the risk of contact with free-living wild boars (Fig.2), which also implies sanitary risk, considering the movement capacity of these animals (Salvador \& Fernandez 2014).

In this study, only $22 \%$ of those interviewed reported seeing the wild boar close to commercial farms (Table 4), and all reports of wild boar sightings were within $1 \mathrm{~km}$ of areas of high environmental suitability for the species, according to the built model. On the other hand, $93 \%$ of sightings occurred within the area of high suitability. These

Table 4. Main responses attributed by the interviewees regarding the wild boar and the areas surrounding the commercial farms in the South of Mato Grosso do Sul, Brazil

\begin{tabular}{|c|c|c|c|c|c|c|c|c|c|c|c|c|}
\hline \multirow{2}{*}{ Questionnaire } & \multicolumn{2}{|c|}{ GRSC* $^{*}$} & \multicolumn{2}{|c|}{ Complete cycle } & \multicolumn{2}{|c|}{ PPU* } & \multicolumn{2}{|c|}{ Nursery } & \multicolumn{2}{|c|}{ Termination } & \multicolumn{2}{|c|}{ Total } \\
\hline & Yes & No & Yes & No & Yes & No & Yes & No & Yes & No & Yes & No \\
\hline $\begin{array}{l}\text { Is the area surrounding the } \\
\text { farm forested? }\end{array}$ & $\begin{array}{c}1 \\
(100 \%)\end{array}$ & $\begin{array}{c}0 \\
(0 \%)\end{array}$ & $\begin{array}{c}1 \\
(100 \%)\end{array}$ & $\begin{array}{c}0 \\
(0 \%)\end{array}$ & $\begin{array}{c}10 \\
(90.9 \%)\end{array}$ & $\begin{array}{c}1 \\
(9.2 \%)\end{array}$ & $\begin{array}{c}0 \\
(0 \%)\end{array}$ & $\begin{array}{c}2 \\
(100 \%)\end{array}$ & $\begin{array}{c}1 \\
(33.4 \%)\end{array}$ & $\begin{array}{c}2 \\
(66.6 \%)\end{array}$ & $\begin{array}{c}13 \\
(72.2 \%)\end{array}$ & $\begin{array}{c}5 \\
(27.8 \%)\end{array}$ \\
\hline $\begin{array}{l}\text { Have you seen wild boars or } \\
\text { javaporcos near the farm? }\end{array}$ & $\begin{array}{c}0 \\
(0 \%)\end{array}$ & $\begin{array}{c}1 \\
(100 \%)\end{array}$ & $\begin{array}{c}0 \\
(0 \%)\end{array}$ & $\begin{array}{c}1 \\
(100 \%)\end{array}$ & $\begin{array}{c}4 \\
(36.4 \%)\end{array}$ & $\begin{array}{c}7 \\
(63.6 \%)\end{array}$ & $\begin{array}{c}0 \\
(0 \%)\end{array}$ & $\begin{array}{c}2 \\
(100 \%)\end{array}$ & $\begin{array}{c}0 \\
(0 \%)\end{array}$ & $\begin{array}{c}3 \\
(100 \%)\end{array}$ & $\begin{array}{c}4 \\
(22.2 \%)\end{array}$ & $\begin{array}{c}14 \\
(77.8 \%)\end{array}$ \\
\hline $\begin{array}{l}\text { Are there any supplementary } \\
\text { methods for wild boar control? }\end{array}$ & $\begin{array}{c}0 \\
(0 \%)\end{array}$ & $\begin{array}{c}1 \\
(100 \%)\end{array}$ & $\begin{array}{c}0 \\
(0 \%)\end{array}$ & $\begin{array}{c}1 \\
(100 \%)\end{array}$ & $\begin{array}{c}1 \\
(9.2 \%)\end{array}$ & $\begin{array}{c}10 \\
(90.9 \%)\end{array}$ & $\begin{array}{c}0 \\
(0 \%)\end{array}$ & $\begin{array}{c}2 \\
(100 \%)\end{array}$ & $\begin{array}{c}1 \\
(33.4 \%)\end{array}$ & $\begin{array}{c}2 \\
(66.6 \%)\end{array}$ & $\begin{array}{c}2 \\
(11.1 \%)\end{array}$ & $\begin{array}{c}16 \\
(88.9 \%)\end{array}$ \\
\hline $\begin{array}{l}\text { Do the surrounding properties } \\
\text { produce any kind of culture? }\end{array}$ & $\begin{array}{c}1 \\
(100 \%)\end{array}$ & $\begin{array}{c}0 \\
(0 \%)\end{array}$ & $\begin{array}{c}1 \\
(100 \%)\end{array}$ & $\begin{array}{c}0 \\
(0 \%)\end{array}$ & $\begin{array}{c}11 \\
(100 \%)\end{array}$ & $\begin{array}{c}0 \\
(0 \%)\end{array}$ & $\begin{array}{c}2 \\
(100 \%)\end{array}$ & $\begin{array}{c}0 \\
(0 \%)\end{array}$ & $\begin{array}{c}3 \\
(100 \%)\end{array}$ & $\begin{array}{c}0 \\
(0 \%)\end{array}$ & $\begin{array}{c}18 \\
(100 \%)\end{array}$ & $\begin{array}{c}0 \\
(0 \%)\end{array}$ \\
\hline
\end{tabular}

${ }^{*} \mathrm{GRSC}=$ Certified Suidae Breeder Farms, PPU = piglet production unit. 

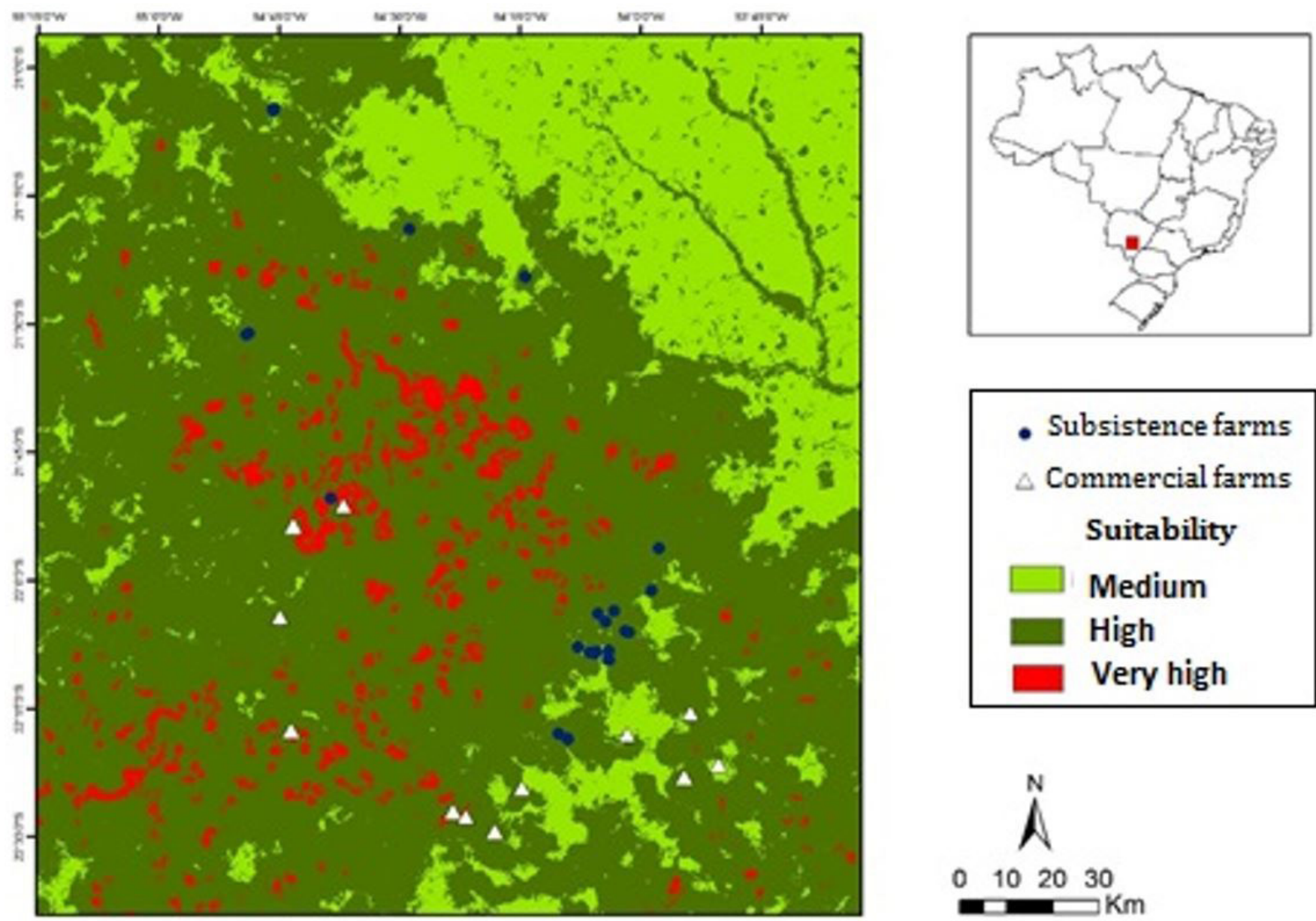

Fig.2. Environmental suitability model for wild boar (Sus scrofa) in Southern Mato Grosso do Sul, Brazil.
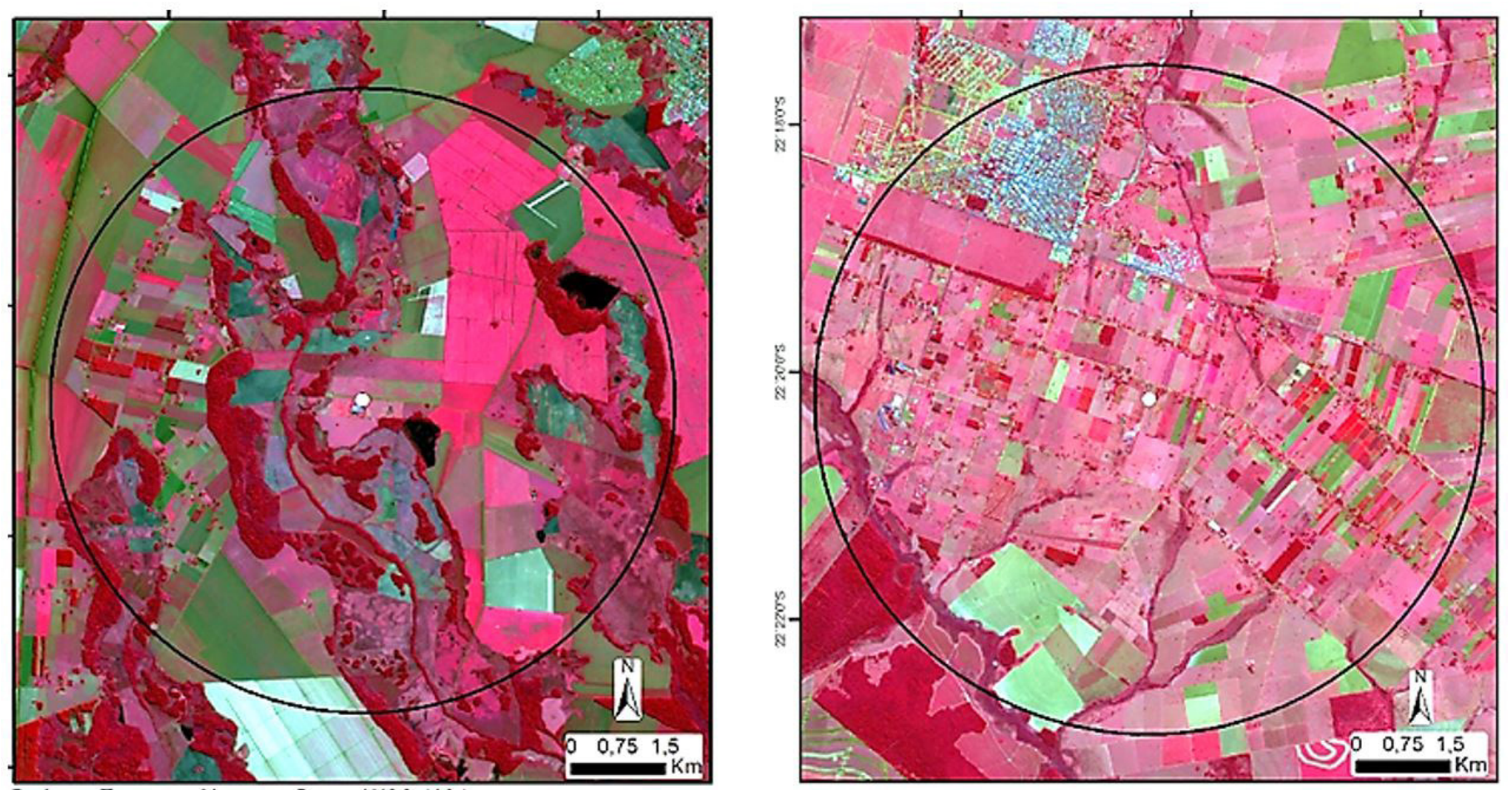

Fig.3. Biosecurity (physical barrier) of one of the swine farms visited in Southern Mato Grosso do Sul, Brazil. 
qualitative results suggest that the model constructed based on habitat requirements of the species in this study can be considered plausible.

All the commercial farms visited in the study area adopted physical biosecurity structures, consisting of resistant fencing fences and masonry (Fig.3), thus ensuring the maintenance of separate internal and external compartments. In the conducted interviews there was no record of wild boar in the internal areas of commercial farms, indicating that this biosecurity measure has been effective. For Bellini et al. (2016) it is of fundamental importance the physical isolation of the production establishments, preventing an infected free-living animal from having contact with the animals of the herd. Still in relation to biosafety in commercial farms, $88.9 \%$ of the respondents stated that they use what is regulated by Normative Instruction/SDA No. 19, which consists of a peripheral fence with a single entrance and a hygiene and disinfection system for the admission of people and vehicles; distance from the nearest uncertified swine production unit or swine slaughterhouse; density of swine herds within a radius of $3.5 \mathrm{~km}$; number of farm supplying swine for replacement purposes; distance from the road carrying swine; quality of the farm's insulation relative to desirable characteristics; quality of the isolation of the farm relative to the existence of green belt and its desirable characteristics, among others.

Of the total of 14 farms interviewed, $72.2 \%$ answered to maintain an environment of the forested farm with eucalyptus as a barrier and security. On the other hand, all the farms around the farms were destined to animal or vegetable production (Table 4), with maize, soybean and sugarcane being the most relevant in the study area. Agricultural regions are of great importance for the survival of wild boars, as they are areas where there is plenty of food throughout the year (Brook \& Van Beest 2014), ensuring the persistence and support of these landscapes for the population of the species. In addition, forested areas provide shelter for the wild boar, where thermal regulation occurs during warm seasons, and serves as a hiding place and refuge. However, wetlands are places where animals find water to be ingested, as well as thermal comfort (Higginbotham 2013, Michel et al. 2017).

In general, the conditions of cover and use of the soil of areas of greater suitability for the wild boar, in comparison with the ones of lesser suitability, are quite clear (Fig.4). At first, areas with lower forest cover and higher human density in the study area have lower habitat conditions for the conservation of wild boar populations. However, in these areas are the majority of subsistence farms that do not adopt biosecurity measures, thus facilitating the occurrence of intrusion of wild boars and crosses with domestic swine (Braz 2017).

For Brook \& Van Beest (2014), a fundamental flaw so far in the management of wild boar control has been the fact that the damage caused by this animal is seen as a biological problem, leaving aside the important social aspects of the wild boar problem. There are intense efforts to publicize the problems and impacts caused by wild boars in crops and deforestation, which leads to loss of natural resources. However, social factors such as loss of production and risk of zoonotic diseases are scarcely reported (Walker et al. 2004). The situation described in this paper indicates that a substantial and adequate effort

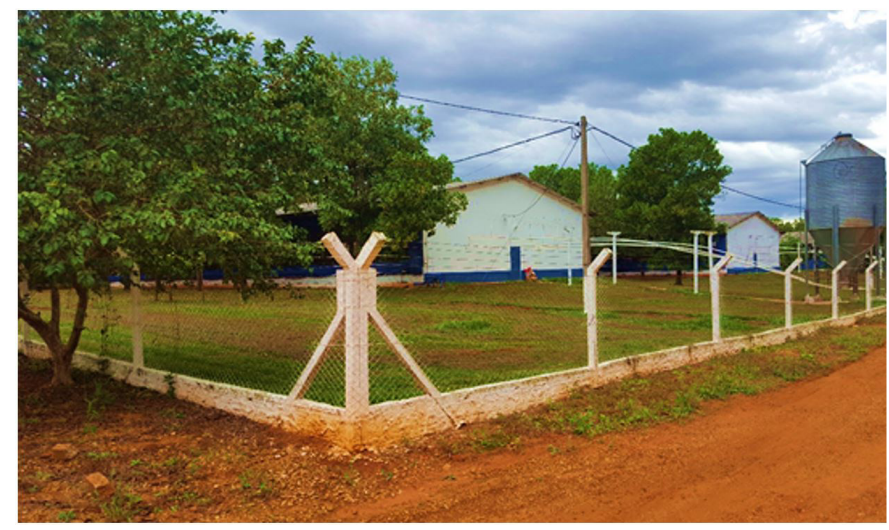

Fig.4. (A) Coverage and land use in areas of $5 \mathrm{Km}$ radius in regions of high environmental suitability, and (B) average suitability for wild boar (Sus scrofa) in Southern Mato Grosso do Sul, Brazil Satellite image Sentinel 2; false color composition RGB-458.

needs to be applied to control populations of wild boars and their free-living hybrids. This need arises from high exposure to sanitary risks, economic damages and environmental impacts, due to the predominance of situations favorable to the species in the study area.

Likewise, subsistence creations in areas where there is a wild boar present a $63 \%$ greater risk of contact with the wild boar, which responds to the sexual attraction of sows in heat, as already demonstrated in Switzerland and the United States. Another aggravating factor is the possibility of swine escape due to the absence of adequate physical barriers in the property and return to a feral or free-living condition, increasing the javaporco population in the region by crossing with the wild boar (Wu et al. 2012). Considering that commercial swine farming is concentrated in the southern region of the state, the potential risk of an increase in the population of javaporco should be subject to constant monitoring so that its management can be undertaken based on technical data.

The population control of wild boar is quite difficult, due to the high growth rate under favorable habitat conditions (Bieber \& Ruf 2005), but may also be expensive. In addition, the effort required for effective population control or its reduction has been reported as large even in regions where hunting is legalized and systematic. Population models developed for Texas indicate that an annual extraction of $66 \%$ may be enough to keep the population stable. Densities can range from over 40 animals $/ \mathrm{km}^{2}$ in wet areas to $1 \mathrm{animal} / \mathrm{km}^{2}$ in drier savannas, going to 4 animals $/ \mathrm{km}^{2}$ in wet areas with freshwater and $3.1 / \mathrm{km}^{2}$ in tropical wet regions of Queensland, Australia. In Texas, the overall density of wild boar varies from 0.47 to 1.0 animal $/ \mathrm{km}^{2}$, although these estimates may be higher depending on habitat quality Based on the percentage of areas of high and very high suitability estimated for the studied region in Southern Mato Grosso do Sul, it is estimated that this area may be home to approximately 12,000 wild boars in a scenario of 0.5 animals $/ \mathrm{km}^{2}$, while in a more pessimistic scenario of 2.0 animals $/ \mathrm{km}^{2}$, this population can surpass 50,000 wild boars and their hybrids in free life. 


\section{CONCLUSIONS}

The constructed model can be considered probable and can be improved with our modeling, validation and extension approaches to other areas of the state. This type of tool can be very useful for the productive sector, environmental agencies and decision makers.

The results of this work indicate that the risk of contact among wild boars and domestic swine is high, and the establishment of strategies for control, monitoring and mitigation of environmental impacts, as well as appropriate biosecurity measures, are essential to deal with this problem that came to stay.

The effectiveness of these measures will depend on the consideration of habitat characteristics, biology and behavior of the species, as well as the establishment of adequate governance to address the magnitude of the problem in its economic, health, social and environmental dimensions.

Acknowledgments.- To the Foundation for Support to the Development of Education, Science and Technology of the Mato Grosso do Sul state (Fundação de Apoio ao Desenvolvimento do Ensino, Ciência e Tecnologia - FUNDECT, CNPq no 16/2014, PHONEX-MS, Process: 59/300.027/2015) for the support of the Pronex project (Structuring of a group of excellence for vertebrate studies applied to the sustainable development of Mato Grosso do Sul state), and by granting of a doctoral scholarship (FUNDECT No. 08/2015); to Embrapa Pantanal for logistical and technical support; JBS/SEARA and rural producers who collaborated with this study.

Conflict of interest statement.- The authors declare no conflict of interest.

\section{REFERENCES}

ABPA 2017. Relatório Anual da ABPA 2017. Associação Brasileira de Proteína Animal. 133p. Available at <http://abpa-br.com.br/setores/avicultura/ publicacoes/relatorios-anuais/2017> Accessed on July 25, 2017.

Afonin A.N., Greene S.L., Dzyubenko N.I. \& Frolov A.N. 2008. Interactive agricultural ecological atlas of Russia and neighboring countries. Economic Plants and their Diseases, Pests and Weeds. Available at <http://www. agroatlas.ru/en/content/pests/Sus_scrofa/map/> Accessed on Jul. 25, 2017.

Bellini S., Rutili D. \& Guberti V. 2016. Preventive measures aimed at minimizing the risk of African swine fever virus spread in pig farming systems. Acta Vet. Scand. 58(1):82. <http://dx.doi.org/10.1186/s13028-016-0264-x> <PMid:27899125>

Bieber C. \& Ruf T. 2005. Population dynamics in wild boar Sus scrofa: ecology, elasticity of growth rate and implications for the management of pulsed resource consumers. J. Appl. Ecol. 42(6):1203-1213. <http://dx.doi. org/10.1111/j.1365-2664.2005.01094.x>

Bosch J., Iglesias I., Muñoz M.J. \& de la Torre A. 2016. A cartographic tool for managing african swine fever in eurasia: mapping wild boar distribution based on the quality of available habitats. Transbound Emerg. Dis. 64(6):114. <PMid:27596983>

Brasil 2016. Instrução Normativa no 25, de 19 de julho de 2016. Ministro de Estado da Agricultura, Pecuária E Abastecimento. 2p. Available at <http:// www.adapar.pr.gov.br/arquivos/File/GTRA/InstrucaoNormativade25072016. pdf> Accessed on June 22, 2017.

Braz P.H. 2017. Indicadores de contato entre populações de suínos domésticos e suídeos asselvajados na região sul de Mato Grosso do Sul. Doctor of Science, Universidade Federal de Mato Grosso do Sul, MS. 72p.

Brook R.K. \& van Beest F.M. 2014. Feral wild boar distribution and perceptions of risk on the central Canadian prairies. Wildl. Soc. Bull. 38(3):486-494. <http://dx.doi.org/10.1002/wsb.424>
FAO/OIE/WB 2010. Good practices for biosecurity in the pig sector, issues and options in developing and transition countries. FAO Animal Production and Health Paper no. 169, Food and Agriculture Organization of the United Nation, World Organization for Animal Health, World Bank. 69p.

Higginbotham B. 2013. Coping with Feral Hogs. Frequently Asked Questions, Wild Pigs. Texas A\&M Agrilife Extension.

IUCN 2012. The IUCN Red List of Threatened Species, Version 2012.2. Available at <http://www.iucnredlist.org/> Accessed on June 22, 2017.

Lowe S., Browne M., Boudjelas S. \& De Poorter M. 2000. 100 of the world's worst invasive alien species, a selection from the global invasive species database. ISSG Invasive Species Specialist Group, Auckland, New Zealand. Available at <s1.downloadmienphi.net/file/downloadfile2/169/1398476. pdf> Accessed on June 22, 2017.

Melis C., Szafranska P.A., Jedrzejewska B. \& Barton K. 2006. Biogeographical variation in the population density of wild boar (Sus scrofa) in western Eurasia. J. Biogeography 33(5):803-811. <http://dx.doi. org/10.1111/j.1365-2699.2006.01434.x>

Michel N.L., Laforge M.P., Van Beest F.M. \& Brook R.K. 2017. Spatiotemporal trends in Canadian domestic wild boar production and habitat predict wild pig distribution. J. Landscape Urban Planning 165:30-38. <http:// dx.doi.org/10.1016/j.landurbplan.2017.05.003>

Mitchel-Jones A.J., Amori G., Bogdanowicz W., Krystufek B., Reijnders P.J.H., Spitzenberger F., Stubbe M., Thissen J.B.M., Vohralik V. \& Zima J. 1999. The Atlas of European Mammals \& EMMA Dataset. Poyser, London. Available at <http://www.european-mammals.org> Accessed on June 22, 2017.

Salgado R.L., Vidigal P.M.P., Gonzaga N.F., de Souza L.F.L., Polêto M.D., Onofre T.S., Eller M.R., Pereira C.E.R., Fietto J.L.R., Bressan G.C., Guedes R.M.C., Almeida M.R. \& Silva Júnior A. 2015. A porcine circovirus 2 mutant isolated in Brazil contains low frequency substitutions in regions of immunoprotective epitopes in the capsid protein. Arch Virol. 160(11):2741-2748. <http:// dx.doi.org/10.1007/s00705-015-2567-z><PMid:26271152>

Salvador C.H. \& Fernandez F.A.S. 2014. Using the Eurasian wild boar phenotype as a basis to document a new processo of invasion by Sus Scrofa L. in a Neotropical biodiversity. Wildl. Biol. Pract. 10(3):22-29.

Semagro 2016. Produção de aves e suínos sobe em MS, mas custos comprometem rentabilidade do produtor. Secretaria de Estado de Meio Ambiente, Desenvolvimento Econômico, Produção e Agricultura Familiar. Available at <http://www.semagro.ms.gov.br/producao-de-aves-e-suinossobe-em-ms-mas-custos-comprometem-rentabilidade-do-produtor/> Accessed on June 22, 2017.

Servanty S., Gaillard J.M., Ronchi F., Focardi S., Baubet E. \& Gimenez O. 2011. Influence of harvesting pressure on demographic tactics: implications for wildlife management. J. Appl. Ecol. 48(4):835-843. <http://dx.doi. $\operatorname{org} / 10.1111 / \mathrm{j} .1365-2664.2011 .02017 . \mathrm{x}>$

Walker B., Holling C.S., Carpenter S.R. \& Kinzig A. 2004. Resilience, adaptability and transformability in social-ecological systems. Ecol.Soc. 9(2):5.<http:// dx.doi.org/10.5751/ES-00650-090205>

Wittenberg R. \& Cock M.J.W. 2001. Invasive Alien Species: a toolkit of best prevention and management practices. CAB International, Wallingford, Oxon, UK. 228p. <http://dx.doi.org/10.1079/9780851995694.0000>.

Wu N., Abril C., Thomann A., Grosclaude E., Doherr M.G., Boujon P. \& RyserDegiorgis M.P. 2012. Risk factors for contacts between wild boar and outdoor pigs in Switzerland and investigations on potential Brucella suis spill-over. BMC Vet. Res. 8:116. <http://dx.doi.org/10.1186/1746-61488-116><PMid:22817843>

Zanella J.R.C., Morés N. \& Barcellos D.E.S.N. 2016. Principais ameaças sanitárias endêmicas da cadeia produtiva de suínos no Brasil. Pesq. Agropec. Bras. 51(5):443-453. <http://dx.doi.org/10.1590/S0100-204X2016000500004> 